\title{
BRNĚNSKÉ ZAČÁTKY RUDOLFA FIRKUŠNÉHO A JEHO STUDIA U LEOŠE JANÁČKA
}

Rudolf Firkušný byl jedním z nejslavnějších pianistů své generace. Ve skladbě byl žákem Leoše Janáčka, Viléma Petrželky a Josefa Suka. Byl důvěrným přítelem Bohuslava Martinů, Vítězslavy Kaprálové a dalších českých a světových skladatelů, jejichž díla mnohdy uváděl ve světových premiérách (z českých jmenujme P. Bořkovce, V. Kaprála, J. Kvapila, O. Chlubnu, P. Janečka, V. Kaprálovou, A. Hábu, J. Ježka; ze zahraničních G. C. Menottiho, S. Barbera, R. Cummingse, P. Glasse, C. Guaneriho, F. Mignoneho, E. Solarese a další). Klavírní lekce navštěvoval nejprve u Ludmily Tučkové, posléze byl žákem v klavírní třídě Růženy Kurzové, která Firkušného učila podle metody svého manžela Viléma Kurze. Kurz se stal posledním českým pedagogem Rudolfa Firkušného. Za zahraničními učiteli se vydal do Paříže (Alfred Cortot), Berlína a Itálie (Arthur Schnabel). Jako pianista podnikal světová turné: projezdil Evropu, Severní a Jižní Ameriku. Vystupoval se světoznámými orchestry a dirigenty počínaje Kusevickým, Walterem, Klempererem, Szellem, Talichem, Mitropoulosem, konče Bernsteinem, Mutim, Mehtou, Bělohlávkem, Neumannem a Abbadem. Během své kariéry prosazoval české autory, především Dvořáka a jeho téměř neznámý klavírní koncert a díla Bohuslava Martinů, z nichž některá byla psána přímo pro Firkušného.

Prameny ke studiu brněnských začátků Rudolfa Firkušného se nachází převážně v Oddělení dějin hudby Moravského zemského muzea (nebo jen ODH MZM) v pozůstalosti, která dosud čeká na své zpracování. Pozůstalost obsahuje Firkušného osobní dokumenty, školní vysvědčení, studentské průkazy z varhanické školy a konzervatoře, programy a plakáty jeho koncertů, výstřižky, fotografie, rodinnou a částečně profesní korespondenci. Dále Firkušného rané skladbičky a jeho vlastní hudebniny. Dalším důležitým zdrojem jsou vzpomínky Rudolfa Firkušného, které byly otištěny v různých periodikách, nebo nahrány a posléze vysílány v rozhlase nebo v televizi. ${ }^{1}$ Dủležitou součástí této pozůstalosti je také

1 Vzpomínkové pořady Rudolfa Firkušného: $Z$ oči do oči Česká televize, pořad Antonína Při- 
nedokončená publikace Richarda Kozderky Život Rudolfa Firkušného v datech, která se dochovala ve strojopisné verzi a pouze v jednom exemplárí. Fragment této zamýšlené knihy zahrnuje Firkušného život od narození přibližně do jeho odchodu z Československa roku $1948 .^{2}$ Tyto prameny, včetně Kozderkovy publikace, měl k dispozici i autor dosud jediné monografie o R. Firkušném Jiř́ Šafařík. ${ }^{3}$

Druhá část pozůstalosti Rudolfa Firkušného se nachází v knihovně Julliard School v New Yorku, kde Firkušný působil jako profesor klavírní hry. Tuto část pozůstalosti věnovala Julliard School po smrti Firkušného jeho dcera Veronique Firkusny-Callegari. Obsahuje rovněž dokumenty z Firkušného dětství, zejména autografy jeho skladeb, notové záznamy z dob studia u Leoše Janáčka, Firkušného vlastní hudebniny, korespondenci, fotografie, osobní dokumenty, články, programy a další materiály. Část Firkušného hudebnin se nachází na Bard College (New York), kde Firkušný také pedagogicky působil. ${ }^{4}$

\section{Dětství a rodové kořeny}

Rudolf Firkušný se narodil 11. února 1912 v Napajedlích, městečku nedaleko Zlína, jako třetí a nejmladší dítě Rudolfa a Karly Firkušných. ${ }^{5}$ Firkušného otec Rudolf byl „c. k. notár v Napajedlích" ${ }^{\text {“6 }}$ a byl synem Josefa Firkušného, hostinského v Chotěboři, a jeho ženy Marie Slámové. Matka Rudolfa Firkušného byla dcera Jindřicha Šindeláře, obchodníka z Červené Řečice a jeho ženy Emilie Suchánkové. Podíváme-li se hlouběji do rodové historie otce, nenalezneme žádné

dala, režie A. Lowák, 1991, 36 minut; Návrat neztraceného syna. Česká televize. Připravili: J. Mihule, P. Kaňka, J. Kadaňka a J. Jireš. 1990, 54 minut; Rudolf Firkušný očima Zdeňka Kopáče. Česká televize. Scénář a režie Z. Kopáč, 1993, 16 minut.

2 KOZDERKA, Richard. Život Rudolfa Firkušného v datech. Brno, nedat. Exemplář nedokončené knihy se nachází v Oddělení dějin hudby Moravského zemského muzea (dále jako ODH MZM), Pozůstalost Rudolfa Firkušného, bez sign.

3 ŠAFAŘíK, Jiří. Rudolf Firkušný. Brno: Nadace Universitas Masarykiana, 1994.

4 Hudebniny na Bard College zatím nejsou zpracovány. Existuje pouze abecední seznam skladatelů, jejichž díla jsou v této části pozůstalosti zastoupena: Ambrose, Axman, del Corona, Correa, Fernandez, Flothius, Floyd, Friml, George, Ginastera, Godowsky, Goldberg, de Graaf, Gradstein, Gratton, Guarneri, Guastavino, Hintze, Keeney, Kohan, Korte, Kune, Lecuna, Long, McDonald, Mahler-Kalkstein, Mana-Zucca, Marescotti, Martinů, de Menasce, Montsalvage, Novák, Pick, Piston, Pizzetti, Reisserová, Respighi, Ricker, Rochberg, Roy, Rózsa, Rudajev, Sarauer, Scelsi, Sheldon, Sérebrier, Shvedoff, Siciliani, Slavický, Smetana, McLeod Smith, Solares, Solima, Staller, V. Štědroň, Stoll, Suchon, Suffern, Suk, Svoboda, Szulc, Támas, Tcherepnin, Triggs, Vačkář, Vianna, Vomáčka, Ward-Steinman, Weis, Wojtowicz, Yrurtia, Zich, Zinn.

5 Informace o rodině R. Firkušného jsou čerpány z jeho rodného listu, ODH MZM, Pozůstalost R. Firkušného, bez sign.

6 Ibid. Podle Jiř́iho Rychetského byl R. Firkušný absolventem jihlavského gymnázia. Viz RYCHETSKÝ, Jiří. Firkušný už na Vysočinu nepřijede. Hudební rozhledy, 1994, roč. 47, č. 9, s. 21. 
stopy hudebního nadání: Rudolfův praděd František byl řezníkem a hostinským. ${ }^{7}$ Na rozdíl od předků otce Firkušného byla rodina jeho matky Karly, rozené Šindelářové, dcery Jindřicha a Emilie Suchánkových, údajně hudebně nadána. Podle J. Šafař́ka byl prapředek Karly František Šindelář dirigentem saského panovnického dvora a je autorem mnoha vánočních pastorel. ${ }^{8}$

Proč se rodina Rudolfa Firkušného usadila právě v Napajedlích, byla víceméně náhoda, jak později vysvětluje sám Rudolf Firkušný: „Do Napajedel se naše rodina dostala čirou náhodou: tatínek byl c. $k$. notár a musel čekat, až se někde uvolni patřičné misto, aby mohl prevzit kancelár̆ a to se stalo v př́hodnou dobu právě v Napajedlích. "9

Rudolf Firkušný měl dva starší sourozence. Nejstarší Leoš ${ }^{10}$ (nar. 16. července 1903, pokřrěn Leopold z úcty ke strýci, ale od malička volán Leoš) ${ }^{11}$ byl významný muzikolog, zakladatel hudebního oddělení dnešní Moravské zemské knihovny, hudební kritik a organizátor. Roku 1948 emigroval se svou ženou a operní pěvkyní Růženou Hořákovou ${ }^{12}$ do Argentiny, kde také zemřel.

Druhorozená Marie Firkušná (nar. 11. ř́jjna 1909) brala zpočátku spolu s Rudolfem lekce klavíru u profesorky Tučkové, mimo to také chodila na hodiny zpěvu a do sboru. Sama vzpomíná, že cvičit na klavír chodila k sousedům a zároveň př́buzným Ningerům, protože doma byl klavír stále obsazen. ${ }^{13}$ Později se stala tanečnicí a členkou baletního souboru Národního divadla v Brně.

$7 \quad$ Kozderka, op. cit, s. 3.

8 Šafařík, op. cit., s. 16. Tuto skutečnost potvrzuje i rodokmen z Firkušného pozůstalosti, ODH MZM, bez. sign.

9 Rychetský, op. cit., s. 21.

10 Firkušný, Leoš (1903-1950), absolvoval hudební vědu u Vladimíra Helferta na Filozofické fakultě Masarykovy univerzity (1934). V letech 1935-39 byl činný jako tajemník Zemského divadla a ve válečných letech 1939-45 byl vedoucím hudebního oddělení Zemské a univerzitní knihovny v Brně. Po r. 1945 se stal vedoucím hudebního oddělení tehdejšího Ministerstva školství a národní osvěty a stál mj. u kolébky mezinárodního festivalu Pražské jaro. Roku 1948 byl pozván s manželkou k přednáškám do Anglie a Jižní Ameriky, kde manželé Firkušní již natrvalo zůstali a zasadili se zde mj. o provedení Její pastorkyně v opeře v Buenos Aires. Viz HNÁTOVÁ, Kateřina. Firkušný, Leoš. In Český hudebni slovník osob a institucí. [online]. <http://www.ceskyhudebnislovnik.cz>.

11 Robert Smetana chybně uvádí, že jména Leoš užíval Firkušného bratr kvůli Leoši Janáčkovi (s. 12). Jejich sestra Marie Kasíková uvádí tento údaj na pravou míru - Leopold Firkušný byl od malička volán Leoš z úcty ke strýci. Viz SMETANA, Robert. Vzpomínky na Rudolfa Firkušného. Brno: JAMU, 2012, s. 12, 33.

12 R. Hořáková (1909-2001) působila v letech 1950-1979 jako sólistka v Teatro Colon v Buenos Aires, kde mj. v představení opery Její pastorkyňa zpívala Kostelničku. Viz MAREK, Peter. Hořáková, Růžena. In Český hudební slovník osob a institucí. [online]. <http://www. ceskyhudebnislovnik.cz>. 


\section{Rudolf Firkušný v Brně}

Firkušní se přestěhovali do Brna v roce 1915, když byli Rudovi právě tři roky. Nečekaně mu zemřel otec, a protože $\mathrm{v}$ Napajedlích nebylo pro matku dost př́ležitostí $\mathrm{k}$ obživě, rozhodla se i s dětmi odstěhovat do Brna. ${ }^{14}$ Ještě před trvalým usazením v Brně bydlela ale rodina po smrti otce nějakou dobu v Bučovicích: „Otec mi zemřel, když mi byly tři roky, ještě v Napajedlích, kde jsem se narodil. Přestěhovali jsme se do Bučovic. Tam jsem trochu klimproval na klavír, jak jsem to uměl. Rozneslo se po městě, že tam je nějaké malé dítě, co hraje na piano." ${ }^{15}$

Podle vzpomínek Firkušného sestry Marie Kasíkové-Firkušné vyplatila Karla Firkušná jako dědička dvoupatrového činžovního domu v Brně na Údolní ulici č. 55 (Talgasse) dalším př́ibuzným jejich podíl (dům dědila po strýci Leopoldu Šindelářovi, vrchním lesním inspektorovi knížete Lichtensteina). ${ }^{16}$ Ve vzpomínkách se dále uvádí, že se Karla Firkušná do tohoto domu s rodinou nastěhovala a jeden $\mathrm{z}$ bytů pronajala př́íbuzným - bratrancům svého zesnulého manžela Ningerům. ${ }^{17}$ Podle sčítání lidu z roku $1921{ }^{18}$ bylo v domě 7 obsazených bytů a dům byl tedy pravděpodobně tř́patrový. $V$ bytě $s$ Karlou Firkušnou a jejími třemi dětmi bydlely ještě 3 mladé dívky - podnájemnice. Ačkoliv je ve sčítacích arších Karla Firkušná vedena jako majitelka domu, ostatní byty (kromě svého) nevlastnila a pronajímala pravděpodobně pouze byt svůj. ${ }^{19}$ Podle popisu R. Firkušného stál dům na Údolní ulici naproti porodnici u Obilního trhu. Měl široký průjezd a velkou ovocnou zahradu směrem na Špilberk, uprostřed které stál zahradní altán. ${ }^{20}$ Dům byl za leteckého bombardování Brna na konci druhé světové války zasažen a posléze zcela zbořen.

Ačkoliv oba Rudolfovi sourozenci dosáhli v oborech jejich působení značného uznání, nikdo z nich nedosáhl takového úspěchu jako jejich nejmladší bratr Rudolf. Ve vzpomínkách a v literatuře se traduje několik historek o tom, jak Ruda již

14 Na tuto událost R. Firkušný vzpomíná: „Tatínek zemřel 12. 7. 1915, kdy mě byly tři roky a tak si na něj, žel Bohu, vůbec nepamatuji." Dále zde také uvádí datum narození otce 14. 4. 1862. Viz RYCHETSKÝ, op. cit., s. 21.

15 Nesmírně dlouhé odloučení. S Rudolfem Firkušným hovořila Marie Kulijevyčová. Hudební rozhledy, 1990, roč. 43, s. 209.

16 Smetana, op. cit., s. 32.

17 Podle Marie Kasíkové-Firkušné se jednalo o Ing. Františka se dvěma syny - první syn MUDr. František Ninger byl profesorem ušních, nosních a krčních nemocí na Masarykově univerzitě v Brně a druhý Karel Ninger byl finanční rada. V roce 1921, kdy bylo provedeno sčítání lidu, bydleli v bytě manželé Ningerovi (František se ženou Zdeňkou) se synem Karlem. Otec František (*1860) byl v té době veden jako ministerský rada na Zemském finančním ředitelství (inspektor technické finanční podpory) a jeho syn Karel (*1890) jako finanční koncipient na Úřadu pro vyměřování poplatků. Viz SMETANA, Robert, op. cit., s. 33.

18 Sběrný arch domovní, Údolní 55. Sčítání lidu v Archivu města Brna (nebo jen AmB), Q 11/2, Městské oddělení Čs. statistického úřadu, Brno, sčítání lidu 1921, krabice č. 25.

19 Ostatní obyvatelé jednotlivých bytů jsou ve sčitání lidu vedeni jako majitelé bytu.

20 SMETANA, op. cit., s. 32-33. 
v raném věku projevoval velké hudební nadání. I sám Firkušný uvádí tyto historky v mnoha rozhovorech. Krátce po narození ho prý otec utišil hrou na klavír se slovy: „Tak ty budeš pořád řvát? Počkej, já tě naučim!‘21 Když byly Rudovi tři roky, začal si vyt'ukávat na klavír melodii písně „Šla Nanynka do zeli", kterou mu zpívala chůva Andělka. ${ }^{22}$ Brzy začal k písni vymýšlet vlastní harmonický doprovod a maminka mu musela pomáhat ,basovat “ ${ }^{23}$ Záhy našla matka Firkušnému prvního učitele hudby. Byl jím Václav Kolář, flétnista divadelního orchestru, který si přivydělával soukromým vyučováním hry na klavír a který bydlel v domě Firkušných. ${ }^{24}$ Kolář se bohužel jako učitel neosvědčil, nechtěl Rudu učit noty a pravděpodobně sám nebyl př́liš valný klavírista. Velmi brzy $\mathrm{k}$ němu malý Ruda odmítal chodit na hodiny: „Nikdo mě však nechtěl vzit před začátkem obecné školy, až nějaký pan Kolár, pikolista a flautista v brněnském Národním divadle, bydleli vedle, a tak mne začal učit [...] Já jsem se však rozhodl, že k panu Kolářrovi už chodit nebudu. Nepomohly ani čokoládové doutníky, které mi slibovali, když do hodiny pơjdu. Postavil jsem si hlavu, že ne a ne, a byla z toho tragédie. Ale na piano jsem si hrál dál po svém. “25 Podle J. Šafaříka nebyl Kolář v klavíru tak fundovaný, a proto se spokojil pouze s tím, že chlapci ukazoval správné prstoklady. Nechtěl jej zatím učit noty, protože se domníval, že je stále ještě prílišs brzo.

\section{U Janáčka}

Po neúspěšných lekcích u Václava Koláře byl Firkušný přiveden k Leoši Janáčkovi: „K nám chodily všelijaké paní a od jedné té paní se o mně dověděl nějaký pan Svěntý, ${ }^{26}$ který aranžoval koncerty a kromě toho měl knihkupectví a prodával hračky. A tento pan Svěntý řekl: ,Tady je jediná věc, toho kluka musí slyšet Janáček. Já ho znám, já to zařidim. 'Janáček mèl tehdy pověst prchlivého pána, který vỉbec nebral na védomi něco takového, čemu se ř́kalo, Wunderkind: Ale já, když jsem se to dověděl, byl jsem u vytrženi, protože poznat Janáčka byl sen mého mladého života." ${ }^{27}$

Ruda Firkušný se tedy poprvé setkal s Leošem Janáčkem v roce 1917, když mu bylo pět let. Byl podroben důkladné zkoušce sluchové i klavírní. Janáček postavil

21 ŠAFǍ̌ÍK, op. cit., s. 18.

22 Ibid., s. 19.

23 SMETANA, op. cit., s. 42. Zde otištěno z původního článku: FIRKUŠNÝ, Rudolf. Můj učitel Leoš Janáček. Svobodné slovo, 1979.

Ibid., s. 42. V roce 1921 v domě s Firkušnými již pan Kolář nebydlel. Viz Sčítání lidu 1921, viz pozn. č. 18 .

Ibid., s. 42.

26 Pravděpodobně se jednalo o Františka Svěntého. Byl veden jako člen Klubu přátel umění - František Svěntý, velkoobchodník. Viz GRYCOVÁ, Kristýna. Klub prátel umění v Brně a Leoš Janáček, př́spěvek k problematice Leoše Janáčka a spolkové činnosti na počátku 20. století. Bakalářská diplomová práce. FF MU Brno 2008, s. 104. 
malého chlapce do rohu své pracovny a přehrával mu akordy a tóny, které Ruda bezpečně poznával. On sám pak Janáčkovi přehrál na klavír vlastní úpravu sboru z Její pastorkyně „Ej, mamko, mamko“ a také osmý Dvořákův Slovanský tanec pouze tak, jak jej někde slyšel a s vlastním doprovodem. ${ }^{28}$ Po zkoušce Janáček při rozmluvě s matkou pronesl údajně větu: „Takový talent se rodí jednou za sto let. “29 Přijal chlapce ke studiu s tím, že on si vezme na starost jeho výchovu hudební a na klavír mu najde jiného učitele. Důrazně také kladl jeho matce na srdce, aby se chlapec podrobil všem ostatním studiím, aby z něj bylo normální dítě a aby s ním nikdo zatím nepodnikal žádná veřejná vystoupení. ${ }^{30}$

Janáček začal Firkušnému dávat soukromé hodiny hudební teorie a kompozice (dvakrát týdně). V publikovaném rozhovoru s Elyse Mach z roku 1980 popisuje Firkušný průběh tohoto soukromého vyučování: „Janáček himself would teach me musical theory and composition. As a piano teacher he recommended Miss Tučková who taught piano and harp at the ,Varhanická Škola' (The Organ School) of which Janáček was director. In the beginning, I visited him twice a week. Later the visits were cut to one a week or whenever he asked to see me. I usually spent anywhere from half an hour to two hours working with him. Nothing was ever planned; each meeting was a surprise for me because everything was so spontaneous. Sometimes we sat together at the piano and played music for four hands; at other times he demonstrated works for me, like Debussy's La Mer; and at still other times he brought out hid latest opera Katia Kabanova, which was almou ready for publication, put it on the the music rack, and asked me to play. It certainly was an unorthodox sort of training. I really never knew for sure just chat each meeting would produce. He did insist, however, that I bring him an originál composition for each session. Together we went over chat I had written and he showed me why he thought I had done certain sections in a particular way or why he thought Theky could have done differently; but he never corrected my manuskript in the strict sense of the word. The why was more interesting to him that the what. I saved all of those early efforts because I wasn't sure yet in which direction I might go, and Theky could bet he foundation of other compositions. I still have them, too, with Janáček's remarks written on them. Janáček was the greatest influence on my musical life. “" ${ }^{31} \mathrm{~V}$ dalších vzpomínkách Firkušný uvádí: „Janáček se ovšem o piano vůbec u mě nestaral. Dal mi jen základní pojmy harmonie a forem. Začal jsem u něj psát maličcké skladbičky a o těch jsme debatovali. Zajímal jsem se o jeho dilo a hltal jsem všechny jeho partitury a sledoval jeho

28 Podle dokumentárního filmu Návrat neztraceného syna. Česká televize. Připravili: J. Mihule, P. Kaňka, J. Kadaňka a J. Jireš. 1990, 54 minut.

29 Toto tvrzení uvádí Jiř́ Šafařík a pak sám Rudolf Firkušný ve svých vzpomínkách. M. Štědroň se domnívá, že tento výrok mohl být později vykonstruován. Viz ŠTĚDROŇ, Miloš. Rudolf Firkušný: 5 tezí. In Rudolf Firkušný. Člověk - pedagog - umělec (ed. Monika Holá). Brno: JAMU, 2012, s. 55-58.

30 Smetana, op. cit., s. 42 . Viz pozn. č. 13.

31 MACH, Elyse. Great Contemporary Pianists Speak for Themselves. New York: Dover Publications, 1991, s. 77-78. 
opery. Svou láskou k jeho tvorbě a pobytem u něj jsem se dostal $k$ této hudbě velice blizko. Byl jsem u něj do svých patnácti let. Takže to byly mé nejpodstatnější roky vývoje. ${ }^{\text {" }} 2 \mathrm{~V}$ rozhovoru s D. Ewenem pak Janáčkovo působení shrnuje slovy: „He opened for me the gates of music." 33

Podle výše uvedených vzpomínek probíral Janáček s Firkušným své vlastní skladby i díla dalších soudobých skladatelů. Janáček také dával Firkušnému zhudebňovat pohádkové př́běhy. Důkazem tohoto tvrzení může být pokus o zhudebnění pohádky s názvem Broučci. ${ }^{34}$ Od roku 1919 do roku 1924 byl Firkušný Janáčkovým žákem v mistrovské škole skladby, kam chodil s daleko staršími spolužáky, jako byl o 15 let starší Břetislav Bakala (nar. 1897), ${ }^{35}$ o 32 let starší Josef Černík (nar. 1880), ${ }^{36}$ o 17 let starší Rudolf Kvasnica (nar. 1895) ${ }^{37}$ a o 5 let starší Rudolf Macudzinski ${ }^{38}$ (nar. 1907, Opatije, Př́́moří). ${ }^{39}$

Hlavním oborem byl však pro Firkušného klavír. Vedle soukromých hodin kompozice u Janáčka a posléze oficiálního studia na mistrovské škole skladby nastoupil Firkušný roku 1917 na varhanickou školu (tzv. nižší kurzy), kde se začal na Janáčkovo doporučení učit u profesorky Ludmily Tučkové, kterou za dva roky vystřídala profesorka Růžena Kurzová, manželka významného pedagoga Viléma Kurze. Ta učila podle proslulé metody svého manžela, ale v méně př́sné verzi. Vedle toho byl Ruda stále žákem obecné školy a později studentem reálného gymnázia na Starém Brně.

Reálné gymnázium navštěvoval Rudolf Firkušný jako mimořádný student na konci každého pololetí konal zkoušky z osmi až deseti předmětů. Protože studoval také na konzervatoři a $\mathrm{v}$ té době již hodně veřejně vystupoval, nebyl jeho prospěch na gymnáziu př́liš dobrý. Když končil kvintu, profesor botaniky dal Firkušnému na vybranou - bud’ řádně dokončí svá gymnaziální studia a zane-

32 KULIJEVYČOVÁ, Marie. Na oběžné dráze světem. Návrat Rudolfa Firkušného. Interveiw. Opus musicum, 1991, roč. 23, s. 195-199.

33 EWEN, David. Musicians Since 1900. New York: The H. W. Wilson Company, 1978, s. 242-244.

34 Partitura uložena na Julliard School v New Yorku (45 F5157br, FirkusnyBxC01f02) s titulem: „Broučci-opera. Napsal Rudolf Firkušný, slova Leoš Firkušný“.

35 Bakala, Břetislav (1897-1958), dirigent, skladatel, sbormistr a klavírista. Viz ZAPLETAL, Miloš. Bakala Břetislav. In Český hudební slovník osob a instituci. [online]. <http://www. ceskyhudebnislovnik.cz>.

36 Černík, Josef (1880-1969), hudební skladatel a sběratel lidových písní. Viz ŠTĚDROŇ, Bohumír. Černík, Josef. In Československý hudebni slovnik osob a institucí. Sv. I. (A-L). Praha: Státní hudební vydavatelství, 1963, s. 189-190.

37 Kvasnica, Rudolf (1895-1986), dirigent a sbormistr. Viz ŠTĚDROŇ, Bohumír. Kvasnica, Rudolf. In Československý hudební slovník osob a institucí. Sv. I. (A-L). Praha: Státní hudební vydavatelství, 1963, s. 800-801.

38 Macudziński, Rudolf (1907-1986), klavírista a skladatel. Viz NOVÁČEK, Zdenko. Macudziński, Rudolf. In Československý hudebni slovnik osob a institucí. Sv. II. (M-Ž). Praha: Státní hudební vydavatelství, 1965, s. 20.

39 KUNDERA, Ludvík (ed.). Výroční zpráva za školní rok 1925-1926. Brno: Státní hudební a dramatická konzervatoř v Brně, 1926, s. 7. 
chá hudby nebo se bude věnovat pouze hudbě a opustí gymnázium. Firkušného spolužák z konzervatoře Robert Smetana vzpomíná, že Rudovi tehdy vyjednal přestup na gymnázium v Bučovicích, kde již Firkušný svá studia zdárně dovedl ke konci (maturoval v roce 1930). Byl zařazen do třídy profesora Antonína Součka. ${ }^{40}$ Podle Roberta Smetany jezdil do Bučovic autem, které dal Rudovi k dispozici brněnský starosta Karel Tomeš. Ruda se za přijetí a umožnění studia odvděčoval gymnáziu v Bučovicích veřejnými koncerty pro studenty školy a bučovické obyvatelstvo. ${ }^{41} \mathrm{Na}$ svá bučovická studia vzpomínal nostalgicky Firkušný v roce 1962 takto: „[...] Byl jsem zapsán do reálného gymnasia v Bučovicích a studoval jsem tam od kvinty $k$ maturitě. Jelikož jsem $v$ tu dobu již studoval na hudební konzervatoři brněnské a později pražské skladbu a dirigování, vedle studia klavírního na mistrovské škole a jelikožjiž jsem také začínal svou koncertní činnost, dojižděl jsem do Bučovic jen na pololetni zkoušky. Ale i v tomto poměrně omezeném styku se školou jsem poznal v Bučovicich pravé prostředi a smysl středni školy. A tyto poznatky na mne zanechaly většì vliv, než mé předcházejicí rádné studium na reálném gymnasiu starobrněnském, kde kromě několika výjimek jsem našel spíse neporozuměni." “

Rudolf Firkušný vzpomínal celý svůj život na Janáčka jako na svého druhého otce. Janáček Firkušnému od malička vykal a choval se k němu mírně a laskavě. Nikdy ho prý př́mo nechválil, vždy jen paní Kurzové. Dával mu zhudebňovat pohádky, které slyšel vykládat nebo viděl v divadle na dětských představeních. Jednal s ním jako s dospělým člověkem, ale přitom nezapomínal, že je ještě dítě. Stále kladl malému chlapci na srdce, že mimo hudbu musí studovat i jiné věci, protože potřebujeme inteligentní muzikanty. Každé Vánoce mu posílal po služebné Maře mísu s cukrovím. Janáček bral malého Rudu také na premiéry svých oper v Brně. Seděl s ním a jeho paní ve své lóži a viděl tak premiéry oper Kát’a Kabanová, Př́hody lišky Bystroušky, ${ }^{42}$ Věc Makropulos, a později, když Janáčkovi bylo 70 let, cyklus všech jeho oper. ${ }^{43}$

Během doby se osobní vztah mezi Firkušným a Janáčkem prohluboval, mluvili o mnoha jiných věcech, ne pouze o hudbě. Hráli avantgardní hudbu, a to jak skladby Janáčkovy, tak Debussyho a Stravinského. Když bylo Rudovi 9 let, poslal mu Janáček partituru Zápisníku zmizelého s věnováním: „Rudolfu Firkušnému k vážné pouti umělecké na cestu přispivá Leoš Janáček, 24. prosince 1921.“44

Firkušného vzpomínka na poslední setkání s Janáčkem nasvědčuje tomu, že Janáček myslel na finanční zajištění svého žáka: „Poslední setkání s Janáčkem

40 Ve třídě bylo celkem 23 žáků. Viz HOLÁSEK, Oldřich (ed.). 60 let střední školy v Bučovicích. Bučovice: SRPŠ při SVVŠ a školská komise při MNV, 1962, s. 47.

41 Smetana, op. cit., s. 14-15.

42 Z této doby pochází také stránky nedatované autografní partitury Janáčkovy opery Př́hody lišky Bystroušky, které pravděpodobně věnoval Janáček Rudolfu Firkušnému. V současné době se nachází v majetku Veronique Firkušný-Callegari v New Yorku, fotokopie uloženy v ODH MZM.

43 SMETANA, op. cit., s. 44.

44 Ibid. 
bylo v červnu 1928, když jsme mu s přtelem Peškem zahráli Houslovou sonátu. Janáček byl zřejmě velmi spokojen, čemuž nasvědčuje jeho děkovný dopis, který mi potom poslal. Také doporučil, abych tuto sonátu hrál v Písku s prof. Kudláčkem. Do svého dopisu prof. C. Vymetalovi prípojil poznámku, aby stejně jako členuim Moravského kvarteta, kteři na koncertě v Písku měli zahrát jeho II. kvartet, zaplatili i mnè cestovné 3. tř́ly z Brna do Písku a zpět. “45

Po ukončení mistrovské školy skladby u Leoše Janáčka studoval Firkušný vedle klavíru v letech 1925-1928 obor skladba a dirigování u J. Kvapila a V. Steinmana. Ve druhém ročníku (1926-1927) byli jeho spolužáky Bernard Pollak, Rafael Schächter ${ }^{46}$ a František Šesták. Ve třetím ročníku (1927-1928) ze tř́ídy odešel F. Šesták. ${ }^{47}$ R. Smetana uvádí ve svých vzpomínkách podle fotografie spolužáků ještě Z. Vavř́ika a sebe samotného. ${ }^{48}$

Je velmi zajímavé, že Firkušného na studiích podporoval prezident T. G. Masaryk. Z klavíristových vzpomínek vyplývá, že první setkání s prezidentem mu zprostředkoval Janáček. Tehdy poprvé přijel Firkušný k Masarykovi do Lán, kde mu hrál na klavír: „To když mi bylo čtrnáct let, pozval mě s maminkou a strávili jsme v Lánech asi čtyři dny. Vím, že jsem mu zahrál Smetanovu koncertni etudu Na břehu mořském. On pak ke mně přišel a zeptal se: ,Vidèl jste někdy moře? No tak se budeme snažit, abyste to moře taky ještě někdy uviděl. 'V Praze na konzervatoři jsem studoval skladbu a současně piano na Mistrovské škole, a tehdy mi prof. Branberger nabidl stipendium na École normale, ale prof. Kurz mi to nechtěl povolit. Přes obtiže dohadů jsem se tam přece dostal. Když jsem se vrátil, pan prezident se mě zeptal, co bych tak jako ještě potřeboval? A já se zmínil o Berlíně, protože tam vyučoval prof. Schnabel. Dostal jsem tedy stipendium ještě do Berlína." ${ }^{49}$ Že o přizeň prezidenta k Firkušnému se zasloužil Janáček, svědčí další úryvek z klavíristových vzpomínek: „Do jisté míry mi opravdu nahradil otce [Janáček - pozn. V. V.]. Snažil se třebas pro mě ziskat finanční podporu od prezidenta republiky. "O finanční podpoře, kterou prezident Firkušnému pravidelně posílal, se pianista vyjadřuje takto: „Masaryk si přál, abych vystudoval reálné gymnázium. Naše domácí ekonomické zázemí bylo dost špatné a vypadalo

Ibid., s. 42-43.

Schächter, Rafael (1905-1944), dirigent a klavírista židovského původu. Na brněnské konzervatoři studoval klavír u V. Kurze a skladbu u K. Kvapila. Poté přesídlil do Prahy, kde studoval v 1. 1928-1933 na konzervatoři skladbu u R. Karla a dirigování u P. Dědečka. Zároveň pokračoval v 1. 1931-1935 na mistrovské škole klavíru u K. Hoffmeistera. Viz KUNA, Milan. Schächter, Rafael. In Český hudebni slovnik osob a institucí. [online]. <http://www. ceskyhudebnislovnik.cz>.

Seznamy studentů viz Výroční zpráva za školní rok 1926-1927. Brno: Státní hudební a dramatická konzervatoř v Brně, 1927, s. 19; Výroční zpráva za školní rok 1927-1928. Brno: Státní hudební a dramatická konzervatoř v Brně, 1928, s. 19; VIČAROVÁ, Eva. Smetana, Robert. In Český hudebni slovník osob a institucí. [online]. <http://www.ceskyhudebnislovnik.cz>.

Fotografie otištěna v: SMETANA, op. cit., s. 39.

KULIJEVYČOVÁ, op. cit., s. 197. 
to, že bych byl nucen si nějak vydělávat penize. A tak abych studium dokončil, dával mi posílat pravidelné asi od čtrnácti let stipendium."

$\mathrm{V}$ katalogových listech brněnské konzervatoře nalezneme ve Firkušného studijních záznamech poznámky o finančních dotacích, které přicházely přímo z kanceláře prezidenta republiky. Ve školním roce 1923/1924 obdržel Firkušný dotaci ve výši 2000 Kč, na rok 1921/1922 mu byla přiděla částka 5000 Kč (k tomu ještě 1200 Kč od Ministerstva školství a národní osvěty a 500 Kč od Moravského zemského výboru) a ve školním roce 1922/23 mu z kanceláře prezidenta republiky přišla částka $3000 \mathrm{Kč}$ ( $\mathrm{k}$ tomu obdržel od Ministerstva během roku postupně $800,1200,2000$ a $600 \mathrm{Kč}) .{ }^{51}$

Přibližně z této doby také pochází Janáčkovy doporučující dopisy pro Firkušného. Jedná se celkem o tři dochovaná doporučení. První dvě pochází z 31. ledna 1922; jedno je rukopisné, druhé psané na stroji s podpisem L. Janáčka. Znění rukopisného doporučení je následující: „P. Rudolf Firkušný vzdělává se skladebně na mistrovské škole skladby. Je zřejmým talentem hudebnim, jenž zasluhuje, aby byl všemožně podporován v době jeho vyspivání. Brno, 31. ledna 1922 Leoš Janáček.“52 Druhé strojopisné zní následovně: „Pan Rudolf Firkušný, jenž vzdělává se skladebně na mistrovské škole skladby, je zřejmý talent hudební. Brno, 31. ledna 1922 Leoš Janáček. "53 Poslední ze tří doporučení je z 10. března 1923 (rukopis L. Janáčka): „Leoš Janáček doporučuje mladičkého Rud. Firkušného vřele. I skladebně rozvíji se utěšeně - když se mu dobrodince dostane, je to pravému člověku [!]. Brno, 10. března 1923 Leoš Janáček. "54 Dodnes není zcela jasné, za jakým účelem Janáček Firkušnému tyto dopisy vyhotovil. Z prvního a posledního znění vyplývá, že se mohlo ve všech prrípadech jednat o přílohy žádosti o finanční podporu na Ministertvo školství a národní osvěty (MŠANO) - 11 . 7. 1922 dostal Firkušný z MŠANO 800 Kč, 9. 12. 1922 - 600 Kč (s poznámkou „,na zaplacení školného“), 31. 1. 1923 - 1200 Kč. 30. 4. 1923 bylo Rudovi z fondu ministerstva vyplaceno 2000 Kč ${ }^{55}$ Finanční tíseň v této době mohla být způsobena Firkušného nástupem na gymnázium, což mohlo znamenat vy̌šśí rodinné výdaje. Doporučení také mohla souviset s plánováním Rudova individuálního programu gymnaziálního studia.

Rudolf Firkušný začal od počátku svých studií na varhanické škole, konzervatoři a mistrovské škole také komponovat. Začínal drobnými klavírními skladbičkami. Jednou z prvních je Zastaveničko komponované pravděpodobně v letech

$50 \quad$ Ibid.

51 Katalogové listy Státní brněnské a dramatické konzervatoře. AmB, školy 277. Klavírní odbor v letech 1919-1926.

52 Doporučující dopis uložen v archivu na Julliard School, New York. Box 2, Series II (Correspondence/Subject Files), N. 16.

53 Šafaŕík, op. cit., s. 20.

54 Ibid.

55 Katalogové listy Státní brněnské a dramatické konzervatoře. AmB, školy 277. Klavírní odbor v letech 1919-1926. 
1917-1919 (v 5 až 7 letech), které věnoval své první učitelce klavíru Ludmile Tučkové. $Z$ dalších jeho dětských skladbiček jmenujme např. Pozdrav sluničku, 3 dvořákovské Humoresky a písně na texty básní z Nerudovy sbírky Písně kosmické. Z pozdějších skladeb se $\mathrm{v}$ archivu dochoval chromatický valčík ,pocta Skrjabinovi“", kterou Firkušný věnoval strýci Jindřichu Šindelářovi. V Praze absolvoval studia na konzervatoři svým vlastním klavírním koncertem. ${ }^{56}$

Ačkoliv byl R. Firkušný pravděpodobně slušný skladatel, nakonec se rozhodl čistě pro kariéru koncertního pianisty. Byl přesvědčen, že pokud se chce kvalitně věnovat jednomu oboru, musí se mu věnovat naplno.

\begin{tabular}{|c|c|c|c|c|}
\hline \multicolumn{5}{|c|}{ STUDIA RUDOLFA FIRKUŠNÉHO V BRNĚ A V PRAZE } \\
\hline \multicolumn{3}{|c|}{ Hudební vzdělání } & \multicolumn{2}{|c|}{ Všeobecné a jiné vzdělání } \\
\hline $1917-1919$ & $\begin{array}{l}\text { Nižší kurzy var- } \\
\text { hanické školy } \\
\text { v Brně (Ludmila } \\
\text { Tučková) }\end{array}$ & $\begin{array}{l}\text { Soukromé } \\
\text { lekce kompo- } \\
\text { zice a hudební } \\
\text { teorie u Leoše } \\
\text { Janáčka (1917- } \\
\text { 1919) }\end{array}$ & $1917-1922$ & $\begin{array}{l}\text { Cvičná škola při } \\
\text { Československém } \\
\text { ústavu ku vzdělání } \\
\text { učitelů v Brně (6 } \\
\text { tř́id) }\end{array}$ \\
\hline 1919-1920 & $\begin{array}{l}\text { Státní hudební } \\
\text { a dramatická kon- } \\
\text { zervatoř v Brně } \\
\text { (Ludmila Tuč- } \\
\text { ková) }\end{array}$ & \multirow[t]{2}{*}{$\begin{array}{l}\text { Mistrovská } \\
\text { škola skladby } \\
\text { (Leoš Janáček) } \\
1919-1924\end{array}$} & $1918-1919,1922$ & $\begin{array}{l}\text { Škola moderních } \\
\text { jazyků (se souro- } \\
\text { zenci) }\end{array}$ \\
\hline $1920-1927$ & $\begin{array}{l}\text { Státní hudební } \\
\text { a dramatická kon- } \\
\text { zervatoř v Brně } \\
\text { - klavírní obor } \\
\text { (Růžena Kurzová) }\end{array}$ & & $1922-1930$ & $\begin{array}{l}\text { České státní reálné } \\
\text { gymnázium v Brně } \\
1926 \text { Gymnázium } \\
\text { Bučovice (maturita } \\
\text { 1930) }\end{array}$ \\
\hline $1925-1928$ & \multicolumn{2}{|c|}{$\begin{array}{l}\text { Státní hudební a dramatická kon- } \\
\text { zervatoř v Brně - obor skladba } \\
\text { a dirigování (Jaroslav Kvapil, Vilém } \\
\text { Steinmann) }\end{array}$} & & \\
\hline $\begin{array}{l}1927 \text { v Brně } \\
1928-1931 \\
\text { v Praze }\end{array}$ & \multicolumn{2}{|c|}{$\begin{array}{l}\text { Státní konzervatoř hudby v Praze } \\
\text { - mistrovská škola - klavír (Vilém } \\
\text { Kurz) } \\
\text { 5. 11. } 1931 \text { absolutorium klavíru }\end{array}$} & $1930-1933$ & \multirow[t]{2}{*}{$\begin{array}{l}\text { Hudební věda na FF } \\
\text { MU (neukončené } \\
\text { studium) }\end{array}$} \\
\hline $1928-1930$ & \multicolumn{2}{|c|}{$\begin{array}{l}\text { Státní konzervatoř hudby v Praze } \\
\text { - kompozice (Josef Suk 1929-30, } \\
\text { Karel Rudolf 1928-29) } \\
\text { 27. 6. } 1929 \text { absolventský koncert }\end{array}$} & & \\
\hline
\end{tabular}

56 Rukopisná partitura Firkušného Koncertu pro klavír a orchestr je uložena v archivu Julliard School v New Yorku. Jedná se o partituru, party (31 F5157cp, FirkusnyBxB01f01) a jednostránkovou skicu (5 F5157com FirkusnyBxC01f05). Na konci partitury poznámka: „Praha 13/V 1929. 1. provedení 27. června 1929 v Praze na Slov. ostrově (Čes. filharmonie, dir. Stupka, klavir: autor).“ 
Veronika Vejvodová je absolventkou hudební vědy a historie na Filozofické fakultě Masarykovy univerzity. Po více jak sedmiletém působení jako kurátorka Janáčkova archivu v Oddělení dějin hudby MZM v Brně je od roku 2013 zaměstnána v Muzeu Antonína Dvořáka, které je součástí Českého muzea hudby - Národního muzea v Praze.

\begin{abstract}
:
Rudolf Firkušný was born in Napajedla in 1912 and his family moved to Brno in 1915 after his father's death. His mother, Karla, and his siblings Leoš and Marie settled in a house in the street Údolní No. 55. When Firkušný yet as a small boy began to show signs of musical talent, his mother arranged for music classes with Václav Koláŕ, a member of the National Theatre orchestra in Brno. In the end, Firkušný took an exam at a composer and at that time director of the organ school, Leoš Janáček. After musical hearing and piano exam, Janáček admitted Rudolph to a piano class at the organ school led by Ludmila Tučková, who was later replaced by Růžena Kurzová. Firkušný then continued his piano studies at the Conservatory with Vilém Kurz. He studied composition in a master class of Leoš Janáček and in a composition and conducting class of Jaroslav Kvapil. The relationship between Janáček and Firkušný is another chapter in the pianist's life. Janáček paid attention to the talented boy with paternal care and understanding. From the beginning, he gave him private lessons in harmony and composition; he let Ruda play his pieces and encouraged him to his own compositional work. He mediated a meeting with President Masaryk, who was granting Firkušný a scholarship and later also arranged for a financial grant for study trips to France and Germany.
\end{abstract}

Key words:

Rudolf Firkušný, Leoš Janáček, Napajedla, Organ school in Brno, Conservatory in Brno, T. G. Masaryk, Brno musical life 1917-1930

\title{
Bibliography:
}

EWEN, David. Musicians Since 1900. New York: The H. W. Wilson Company, 1978, s. 242-244. GRYCOVÁ, Kristýna. Klub přátel umění v Brně a Leoš Janáček, př́spěvek k problematice Leoše Janáčka a spolkové činnosti na počátku 20. století. Bakalářská diplomová práce. FF MU Brno 2008.

HNÁTOVÁ, Kateřina. Firkušný, Leoš. In Český hudebni slovník osob a institucí. [online]. $<\mathrm{http}: / /$ www.ceskyhudebnislovnik.cz>.

HOLÁSEK, Oldřich (ed.). 60 let středni školy v Bučovicich. Bučovice: SRPŠ při SVVŠ a školská komise při MNV, 1962.

KOZDERKA, Richard. Život Rudolfa Firkušného v datech. Brno, nedat.

KULIJEVYČOVÁ, Marie. Na oběžné dráze světem. Návrat Rudolfa Firkušného. Interview. Opus musicum, 1991, roč. 23, s. 195-199.

KUNA, Milan. Schächter, Rafael. In Český hudebni slovnik osob a institucí. [online]. <http://www. ceskyhudebnislovnik.cz>.

KUNDERA, Ludvík (ed.). Výroční zpráva za školní rok 1925-1926. Brno: Státní hudební a dramatická konzervatoř v Brně, 1926.

MACH, Elyse. Great Contemporary Pianists Speak for Themselves. New York: Dover Publications, 1991.

MAREK, Peter. Hořáková, Růžena. In Český hudebni slovnik osob a institucí. [online]. <http:// www.ceskyhudebnislovnik.cz>. 
NOVÁČEK, Zdenko. Macudziński, Rudolf. In Československý hudební slovník osob a institucí. Sv. II. (M-Ž). Praha: Státní hudební vydavatelství Praha, 1965, s. 20.

RYCHETSKÝ, Jiří. Firkušný už na Vysočinu nepřijede. Hudební rozhledy, 1994, roč. 47, č. 9, s. 21. SMETANA, Robert. Vzpomínky na Rudolfa Firkušného. JAMU Brno 2012.

ŠAFAŘÍK, Jiří. Rudolf Firkušný. Brno: Nadace Universitas Masarykiana, 1994.

ŠTĚDROŇ, Bohumír. Černík, Josef. In Československý hudební slovník osob a institucí. Sv. I. (A-L). Praha: Státní hudební vydavatelství, 1963, s. 189-190.

ŠTĚDROŇ, Bohumír. Kvasnica, Rudolf. In Československý hudebni slovník osob a institucí. Sv. I. (A-L). Praha: Státní hudební vydavatelství, 1963, s. 800-801.

ŠTĚDROŇ, Miloš. Rudolf Firkušný: 5 tezí. In HOLÁ, Monika (ed.): Rudolf Firkušný. Člověkpedagog-umělec. Brno: JAMU, 2012, s. 55-58.

VIČAROVÁ, Eva. Smetana, Robert. In Český hudebni slovník osob a institucí. [online]. <http:// www.ceskyhudebnislovnik.cz>.

ZAPLETAL, Miloš. Bakala Břetislav. In Český hudební slovník osob a institucí. [online]. <http:// www.ceskyhudebnislovnik.cz>. 
